\title{
BIOLOGIESE UNIEKHEID AS SUBSTRAAT VIR DIE TIPIES MENSLIKE FUNKSIONERING
}

P.A.J. Ryke, Buro vir Navorsing, Potchefstroomse Universiteit vir $\mathrm{CHO}$

\section{ABSTRACT}

BIOLOGICAL UNIQUENESS AS A SUBSTRATE FOR SPECIFICALLY HUMAN FUNCTIONING

The biological similarities between humans and apes are great but they should not obscure the differences. Some differences are of such great consequence that man should be considered a truly unique kind of organism with a marvellous plasticity of mind. All of the uniquely human traits are adaptations to the environments in which man evolved; these include profound modifications of anatomy, physiology and behaviour.

The morphological differences between man and his nearest relatives are very conspicuous. The form of the skeleton is adapted to fully erect posture and bipedal locomotion. The pelvis is broadened to provide adequate attachment for the powerful striding muscles. The transformation of the tail vertebrae is unique among the vertebrates. The joint for the neck is in the middel of the base of the skull. The hands are prehensile, with a large and strongly opposable thumb. The brain is uniquely large in proportion to the body and has a particularly large and complex cerebrum; the cerebral cortex contains the centres for memory and complex computation. The enlarged brain requires prolonged infant dependency and high quality nutrition.

Differences between humans and animals are greatest in the realm of behaviour: Ability to make tools (associated with bipedalism); ability to anticipate the future; development of symbolic communication (associated with expansion of cortex). Direct evidence of man's language capabilities comes form the anatomy of the modern human vocal tract. Man is the only species that succeeded in creating a truly productive language, and it is the scaffolding of human culture and civilization.

Koers 54(1) 1989 
Projects devoted to teaching chimpanzees and gorillas to use language have shown that these apes can learn vocabularies of visual symbols. There is no evidence, however, that apes can combine such symbols in order to create new meanings. The function of the symbols of an ape's vocabulary appears to be not so much to identify things or to convey information as it is to satisfy a demand that it uses that symbol in order to obtain some reward. Human babies find language rewarding in itself and do not require constant food rewards or positive social interaction for correct vocalizations. Even neglected or abused children will develop effective speech.

Inborn knowledge and capacities underlie the use of language, and the process of language acquisition in man begins well before the first birthday. Speech perception studies show that young children are richly endowed with innate perceptual mechanisms, well adapted to the characteristics of human language. The effectiveness of these mechanisms is reflected in the swiftness with which a child joins the community of language. The gift of language alone sets man apart from the rest of the living world and gives him enormous advantages in his adaptation to his environment and in his social organization; it is a mechanism for communication and for cultural transmission from one generation to the next. All human languages give the power to talk about things that are elsewhere or elsewhen.

Humans are but one of the interacting structures in ecosystems, but they are also the most powerful species in effecting alteration in ecological processes. They also have responsibility for the environment far outsurpassing the responsibility of other species. That responsibility is being a steward and guardian, an imperative based on man's unique capacities for cognition, reflection, and prediction. In contrast to all other species, humans can voluntarily control their environment, their population, as well as their behaviour and genetic heritage. Therefore, man must develop an ecological conscience, a love, respect, admiration and understanding for the total ecosistems, including other people, and an ethic that ensures the survival of the human species with quality, dignity and integrity. 
Geestes- en gedragsoepelheid en kultuurbeoefening op 'n hoë vlak besorg aan die mens $n$ unieke posisie in die biologiese wêreld. Alle lewende wesens op aarde het talle besonder suksesvolle lewenseienskappe, maar van die biljoene individue en die enorme getalle uitgestorwe spesies, is dit slegs die mens wat 'n groot komplekse brein, 'n unieke regoploopwyse, 'n spraakvermoë, selfbewussyn en 'n spesiale lewenswyse het wat na willekeur aangepas kan word. Voeg daarby die mens se sin vir die estetiese en morele waardes dan het ons al 'n belangrike deel van menswees getipeer. Dit hou nie in dat alle mense se handel en wandel eenders is en vas geprogrammeer is nie, want ten opsigte van taal, ambagte, vaardighede, sosiale gebruike, tradisies en inligting wat verskaf en ingeneem word in 'n samelewing, verskil mense, in 'n hoë mate van mekaar. Maar dit is juis hierdie kulturele kompleksiteit en soepelheid wat nèrens anders in die organismewereld aangetref word nie.

Die biologiese ooreenkomste tussen mense en ape is nogal groot, maar hulle moenie die belangrike verskille versluier nie, want die mens is beslis nie maar net 'n naakte, pratende, regoplopende aap nie. Al die unieke menseienskappe is aanpassings aan omgewings waarin die mens hom bevind of bevind het; dit sluit molekulère, fisiologiese, morfologiese en gedragswysiginge in.

\section{MOLEKULËRE EN FISIOLOGIESE ASPEKTE}

Uit ondersoeke weet ons dat die chemiese samestelling van twee naverwante spesies meer eenders sal wees as diè van twee onverwante spesies; daarom word hierdie biochemiese homologie gebruik om verwantskappe te bepaal. Molekulère vergelykings tussen ape en mense toon dat die verskille oënskynlik eintlik baie klein is (Weiss, 1987). Sitochroom C, 'n proteien wat by suurstofvervoer betrokke is, bestaan byvoorbeeld, by werweldiere uit 104 aminosure (Dickerson, 1980); al 104 aminosure is dieselfde en verskyn in identiese volgordes by die mens en die groot ape (sjimpansees, gorillas, oerangoetangs). Die alfa- en betahemoglobienkettings, wat uit 141 en 146 aminosure respektiewelik bestaan, is identies by mense en sjimpansees, en verskil by die gorilla slegs ten opsigte van een aminosuur. King $\varepsilon$ Wilson (1975) het bereken dat die mens en die sjimpansee slegs ten opsigte van een in elke 100 aminosure in hulle proteiene verskil.

$-90-$ 
Chromosome van die mens en die sjimpansee is ook merkwaardig eenders. Dit geld chromosoom vir chromosoom en band vir band, behalwe vir in paar chromosoomherrangskikkings, insluitende 'n versmelting van twee sjimpanseechromosome tot een by die mens; die mens het dus 46 chromosome terwyl die ape 48 het. Volgens data wat elektroforeties verkry is, is die gemiddelde genetiese afstand tussen die mens, gorilla, sjimpansee en oerangoetang 0,355 Darwins, wat vergelykbaar is of selfs minder is as diè tussen spesies van dieselfde genus (Bruce \& Ayala, 1979). in Tegniek wat tans gebruik word om genetiese afstande tussen spesies van dieselfde genus (Bruce \& Ayala, 1979). 'n Tegniek wat tans gebruik word om genetiese afstande tussen spesies te meet is die sogenaamde molekulère klokondersoeke (Hasegawa et al., 1985). Molekulère klokke is biologiese molekule met veranderingstempo's wat min of meer konstant is in evolusionère tyd, en van al die sodanige molekule gee DNA die mees direkte inligting ten opsigte van die genetiese afstand tussen spesies; dit behels die bepaling van die ligging van dieselfde geen in die DNA van verskillende spesies. Enkele veranderinge in die volgorde van nukleotiede gee 'n aanduiding van die chronologiese verband tussen die gene. Hasegawa et al. is die eerste navorsers wat DNA-volgordedata bestudeer het om die mens-aapsplitingstyd te bepaal. Dit moet egter beklemtoon word dat klein genetiese verskille geweldige gedragsverskille tot gevolg kan hè - soos duidelik blyk uit die gedragsgaping tussen mens en aap. Nieteenstaande die hoë mate van molekulère en genetiese ooreenkomste kan deur 'n ontleding van die proteïene in 'n druppel bloed of 'n klein stukkie weefsel ondubbelsinnig vasgestel word aan watter spesie die monster behoort.

Fisiologies verskil die mens en ape nie in baie opsigte nie, maar daar is tog verskille wat besonder belangrik is. Die voortplantingsbiologie van die mens is uniek met betrekking tot die identifisering van menstruasie en die feit dat ovulasie en kopulasie dwarsdeur die jaar kan plaasvind. Hierdie nie-seisoengebonde voortplantingsaktiwiteite speel in belangrike rol in die oorlewing van die spesie, mar hou natuurlik die groot gevaar van oorbevolking in. Die mens het egter die vermoë om bevolkingsgroei binne perke te hou.

Termoregulering is 'n belangrike fisiologiese proses in warm (en koue) dele van die wèreld. 'n Verkoeler in die neus (in die vorm van 'n ver$-91-$ 
dampingsoppervlak) en hitteuitruilingsarteriole in 'n sinus onder die skedelbasis stel die meeste soogdiere in staat om hulle breine koel te hou, selfs al is hulle liggame baie warm. Dit is ' $n$ belangrike aanpassing, want die sentrale senuweestelsel is besonder gevoelig vir hitte. Primate besit egter nòg verkoeler nog hitteuitruiler en kan baie min doen om hulle breine af te koel as hulle liggame oorverhit. Om hulle groot en delikate breine te beskerm moet primate dus op een of ander manier verhoed dat hulle kerntemperatuur styg. By die moderne mens kan 'n styging van selfs 1 of $2^{\circ} \mathrm{C}$ breinfunksie belemmer. Hitteslag (sonsteek), wat 'n kwaai en dikwels dodelike versteuring van die sentrale senuweestelsel is, is die gevolg van 'n styging in kerntemperatuur van slegs $4^{\circ} \mathrm{C}$.

Selfs sonder direkte sonskynhitte kan hipertermie by sjimpansees intree wanneer die omgewingstemperatuur bokant $40^{\circ} \mathrm{C}$ styg. Wheeler (1988) meen dat regoploop een moontlike antwoord kan wees op die probleem om koel te bly of om hitte vinnig te verloor. Regoploop is die ideale manier om koel te bly in ' $n$ tropiese omgewing. Wanneer die son reg bokant en op sy warmste is, stel 'n regoplopende dier minder van sy liggaamsoppervlak aan die son se strale bloot en absorbeer dus minder (60\%) hitte as een wat handeviervoet loop. 'n Ander termoregulerende voordeel van regoploop is dat dit die liggaam hoër bokant die warm grondoppervlak hou, wat 'n groter deel van die vel in staat stel om die liggaam hitte te help verloor. Windsnelheid verhoog en lugtemperature daal soos verder van die grond af beweeg word en beide is faktore wat help om hitte vanaf die vel deur konveksie te verwyder. Dikwels is humiditeit hoër naby die grond en tussen plantegroei en dit verswak ook die moontlikhede van vinnige verdamping by viervoetiges. Die groot belang van hierdie feite vir die vroeë mens was natuurlik dat, in teenstelling met diere, hulle dwarsdeur ' $n$ warm dag voedsel kon versamel. Termoregulering kan dus in nove verband met regoploop gebring word.

Daar is sterk aanduidings dat ' $n$ ander unieke kenmerk van die mens liggaamshaartipe - in hierdie verband ook 'n rol speel. Ten opsigte van algemene voorkoms is dit opvallend dat die mens nie baie harig is nie, wat moontlik as in aanpassing aan warm omgewingstoestande beskou kan word. Alhoewel die mens min of meer net soveel hare per vierkante sentimeter as ' $n$ sjimpansee het, is hulle hoofsaaklik korter en fyner haartjies. Hierdie funksionele naaktheid, tesame met goed ontwikkelde 
sweetkliere, stel die mens in staat om hitte teen 'n verbasende koers van 700 watts per vierkante meter vel te verloor, 'n tempo wat geen lewende soogdier naastenby kan handhaaf nie. Dit word moontlik gemaak deur die anwesigheid van tussen twee en vyf miljoen sweetkliere in die vel, 'n getal wat baie meer is as wat by enige primaat aangetref word. Baie dierspesies wat in savannestreke voorkom, het wel sweetkliere, maar hulle dik pels verhoed die vrye vloei van lug oor die nat oppervlak van die vel. So ' $n$ pels dien wel as ' $n$ hitteskild, maar in daardie opsigte word die mens se kop en skouers ook deur 'n haardos beskerm; die res van die mensliggaam trek egter voordeel uit verdampingsafkoeling.

Die drie belangrikste anatomies/fisiologiese kenmerke wat mense van ander primate skei, is waarskynlik nie onafhanklike verwerwings nie: Hulle is deel van 'n stel funksioneel verbandhoudende aanpassings waarvan twee - regoploop en 'n naakte vel - ontwikkel het om die derde een - 'n groot en komplekse brein - teen die hittestres van die omgewing te beskerm. Dit is dus nie toevallig dat die mens, wat die hoogste ontwikkelde brein het, ook met die kragtigste en doeltreffendste afkoelingstelsel om dit te beskerm, toegerus is nie (Wheeler, 1988).

\section{BIPEDALITEIT}

Benewens sy naaktheid is die opvallendste uiterlike kenmerk van die mens die feit dat hy regop loop - 'n verskynsel bekend as bipedalisme. Byna alle primate kan op hulle agterpote staan, en baie van hulle loop soms op hierdie wyse, maar almal is amateurs in vergelyking met die mens se benutting van bipedaliteit. Hierdie uniekheid is egter nie sonder probleme nie en Napier (1967) beskou dit so: "Human walking is a unique activity during which the body, step by step, teeters on the edge of catastrophe ... because only the rhythmic forward movement of first one leg and then the other keeps him from falling flat on his face." Die doeltreffendheid van regoploop het te make met die liggaamshouding wat deur skelet- en spieraanpassings van veral die voet en bekkengordel moontlik gemaak word.

Regoploop op twee bene in plaas van handeviervoet behels in verandering in die posisie van die swaartepunt van bokant en tussen die vier bene $-93-$ 
na bokant en tussen die twee bene (Ryke, 1987a en b). Wanneer ' $n$ mens staan, word die gewig van die romp en die boonste dele van die liggaam omtrent alles deur die werwelkolom gedra wat afwarts inwerk op die sakro-ilium. Kwadrupedale diere het 'n geboë werwelkolom van die sakro-ilium na die skouergordel, vrygedraag soos 'n brug deur die afwaartse kragte van die romp en kop. Mensbabas word met 'n geboë primére kurwatuur (kromming) van die ruggraat gebore, maar daarna ondergaan dit 'n sekondère kurwatuur deur die ontwikkeling van twee retrofleksies (buiging in ' $n$ ander rigting). Die eerste retrofleksie kom in die baba se nek voor deurdat die nekwerwels agterwarts buig om die kop op te lig sodat dit vorentoe gerig is. Die tweede en groter retrofleksie is in die lendewyk war die lendewerwels se sentrums en intervertebraalskywe meer aan die anteroventrale kant uitbrei as wat dorsaal die geval is; die gevolg is dat hulle wigvormige, silindriese eenhede word. Hierdie groeiverandering vind plaas wanneer die kind leer loop. Die resulterende kronkelkolom (S-vormig) van die ruggraat besit drukvastigheid sowel as veerkragtigheid.

By die mens is die knieë naby mekaar onderkant die swaartepunt, maar die bekken is breed om genoeg spieraanhegtingspunte vir die loopstyl moontlik te makk. Dit het gepaard gegaan met ' $n$ wysiging van die femur. In vergelyking met die ape het die femur 'n langer nek en die distale kniegewrig is met so 'n hoek tot die skag geplaas dat dit horisontaal artikuleer. Nieteenstaande hierdie inbringproses van die knieë, onder die swaartepunt, sal daar nog 'n neiging van die bekkengordel wees om aan dieselfde kant af te sak wanneer een been tydens die loopbeweging gelig word. Dit word by die mens teëgewerk deur die sametrekking van abduktorspiere wat vanaf die ilium (heupbeen) na die bopunt van die femurskag strek.

In vergelyking met ape het die struktureel komplekse bekkengordel in 'n hoë mate van vorm verander, 'n verskynsel wat natuurlik nou samhang met die verandering van die hoek van die femur tot die werwelkolom en die veranderde funksie van die geassosieerde muskulatuur. Dit is veral die bekken, in sy rol as anker vir die belangrike spiere vir vorentoe beweging en laterale ewewig, wat verbreed het om hierdie spiere groter hefvermoë om die heupgewrig te gee. Die bekkenholte het saam met die werwelkolom ' $n$ herrangskikking ondergaan 
en gee noodsaaklike steun aan die ingewande. In hierdie verband het die mens ook 'n unieke kenmerk as gevolg van die verkorting van die stert tot ' $n$ paar versmelte werwels, die stuitjie, wat deel vorm van die vloer van die bekken; dit is ' $n$ kenmerk wat by geen vertebraat voorkom nie.

Die loopbene van die mens is reguit en die hele liggaamsgewig word direk deur die kniegewrig van die asetabulum na die enkel oorgedra. Die bene is ook langer in verhouding tot die arms en die romp sodat die kenmerkende liggaamsproporsie van die ape nie hier voorkom nie. Die voet en enkel is ook in 'n hoë mate gewysig. In vergelyking met die van die aap is die enkelgewrig redelik stram en kan nie maklik links na regs gedraai word nie; die voet kan egter maklik ondertoe wys. Daar is ' $n$ groot kalkaneum (hakbeen) waaraan 'n goed ontwikkelde Achillestendon geheg is wat vir die aanhegting van die kuitspiere dien en 'n kragtige strekking van die voet moontlik mak. Wanneer uitstrekking tydens voortbeweging plaasvind, sal dit nie platvoetig wees nie, mar dit voorsien, met elke tree, 'n voortdrywings- en opheffingskrag. Die hele bou van die voet is gewysig vir hierdie voortdrywingselement.

\section{Vrykoms van arms}

'n Baie belangrike voordeel van bipedaliteit is die vrykoms van arms en hande om voorwerpe te kan hanteer (Stringer, 1982). In kwadrupedale voortbeweging by die meeste primate word beide die hand en voet plat op die grond geplaas (plantigraad); die diere kan dus nie enigiets met hulle saamdra terwyl hulle loop nie. Gorillas en sjimpansees het egter 'n vorm van voortbeweging ontwikkel wat as kneukelloop bekend staan; dit stel hierdie ape in staat om normaalweg te loop terwyl hulle voorwerpe tussen hulle vingers en die handpalm dra. Hierdie kneukellopende liggaamshouding van basies halfregop-kwadrupede kom op die grond sowel as op stewige horisontale boomtakke voor (Tuttle, 1969). Die distale en middelsegmente van die vingers is dan gebuig en die proksimale segmente hipergestrek. Die palms word gelig en in lyn met die pols en voorarm gebring.

By die kneukellopers kom dus slegs die rugkant van die middelsegmente van die vingers in aanraking met die substrat. Die mening is uitge$-95-$ 
spreek dat die mens se voorvaders dalk kneukellopers was voor hulle bipedaal geword het (Washburn, 1978), mar Tuttle kon geen aanduiding in die bene, ligamente of spiere van die mens se hand vind wat op so ' $n$ stadium dui nie. Die beskikbare fossielgetuienis van vroeë hominiede toon ook geen blyke van die moontlikheid van so in tussenstadium nie. Dit lyk eerder of die begin van skrydingsbewegings direk op bragiasie (takswaaing) gevolg het wat die arms vir ander doeleindes vrygestel het.

Die gebruik van werktuie het reeds by vroeë hominiede voorgekom. Die teenwoordigheid van werktuie in assosiasie met fossielbene word, trouens, as $n$ kriterium gebruik om mensstatus aan sodanige oorblyfsels te gee. Die gebruik van stokke, blare en klippe deur wilde primate is algemeen bekend, asook hulle buitengewone vermoë om selfs in gevangenisskap menslike werktuie te manipuleer (Pilbeam, 1984). Sjimpansees kan selfs eenvoudige werktuie fatsoeneer, byvoorbeeld om grasse of stokke sodanig te verander dat hulle dit kan gebruik om termiete uit 'n nes te haal (Van Lawick-Goodall, 1968; 1971), of selfs vir verdediging.

As werktuiggebruik by die vroeë hominiede gepostuleer word, kon dit $n$ belangrike komponent van daardie tipe gedrag gewees het wat voortbeweging op twee bene en die reduksie van die kanini gestimuleer het. In hierdie verband moes die hande $n$ belangrike rol gespeel het. Eintlik is die hand en arm anatomies nog relatief primitiewe strukture want dit het nog die basiese voorkoms van die pentadaktiele ledemaat. Die behendigheid waarmee dit funksies by die moderne mens vervul is egter beslis nie primitief nie; hierin speel die ontwikkelde brein natuurlik die hoofrol, terwyl die grypvermoë van die hande met opponerende duim doeltreffendheid baie verhoog

Die mens is nie slegs ' $n$ werktuiggebruiker nie, maar ook $n$ werktuigmaker en die ontwikkeling van tegnologie het in ' $n$ hoë mate bygedra tot sy biologiese sukses (Beals et al., 1977). Werktuigvervaardiging by die mens is soms baie gekompliseerd en hou dikwels ook verband met tradisie. Voorts gebruik mense ook sekondère werktuie, dit wil sè werktuie om werktuie te maak. Dit verg dikwels meer as handvaardigheid om voorwerpe op 'n voortreflike wyse te kan maak (Ayala \& Valentine, 1979). Die ontwerp en konstruksie van werktuie hang af van die vermoë om vooraf presies te kan sien hoe hulle as instrumente $n$ bepaalde funksie $-96-$ 
kan dien. Moderne mense kan die verband sien tussen die middele en die doel wat hulle dien, tussen verwagte behoeftes en die werktuie of instrumente wat aan sulke behoeftes kan voldoen.

Die belangrikste werktuig wat die mens reeds lank tot sy beskikking het, is vuur, iets wat ekologiese omstandighede radikaal verander het: Dit het aan die mens die vermoë gegee om verskeie andersins oneetbare wortelgewasse op 'n verteerbare wyse voor te berei en het sodoende sy oorlewingsbasis vergroot. Vuur het ook die mens gehelp om ander werktuie te makk, om lig en hitte te verskaf en om predatore af te skrik. Die psigologiese transformasie van vroeè mense wat bang was vir vuur na wesens wat vuur kon beheer en gebruik, was in baie belangrike stap in die moderne mensweesproses (Bourguignon, 1976).

\section{NEOTENIESE EIENSKAPPE}

Dit word tans algemeen aanvaar dat neotenie 'n belangrike rol in die evolusie van die mens gespeel het (Ryke, 1986). Dit is die verskynsel waar larwale kenmerke selfs tot in die volwasse stadium behoue bly. Die mening is dat die gemeenskaplike voorvader van die mens en die ape eerder meer na laasgenoemde gelyk het. Die rede waarom die mens as neotenies beskou word is - soos eerste deur Bolk (1926) uitgewys - dat hy in baie opsigte meer lyk soos 'n jong aap as na 'n volwasse aap, en dus, by implikasie, dat hy 'n groter ooreenstemming toon met die jeugstadia van sy voorvaders as met hulle volwassenes. Sommige van die aspekte warin die mens eerder met 'n jong as ' $n$ volwasse aap ooreenstem is die volgende:

Die ontwikkeling van die kop van die mens is ten opsigte van skedel, brein en gesig relatief vertraag. Na geboorte groei die kop, insluitende die brein, nog teen 'n tempo wat vergelykbaar is met die van 'n fetus by ape. Die relatiewe verhouding van skedelgrootte tot liggaamsgrootte is ongeveer dieselfde by pasgebore ape en mense, terwyl volwasse ape baie groter liggame het in verhouding tot hulle koppe as wat die geval by die mens is. Die sluiting van nate tussen die skedelbeen, wat by ape voor geslagsrypheid geskied, word by die mens vertraag tot 'n ouderdom van tussen 25 en 30 jaar. 
Die verlenging van die onderste deel van die gesig wat aan gorillas en sjimpansees hulle kenmerkende vooruitstekende kake en lippe gee, is by mense afwesig. Die vorm van die kop by volwasse sjimpansees en gorillas verskil baie van dié van hulle kleintjies; by mense verander die kopvorm egter relatief min vanaf geboorte tot volwassenheid. Die kopprofiel van 'n babasjimpansee lyk baie meer na die kop van 'n mensbaba of -volwassene as wat dit na die kop van 'n volwassene van hulle eie spesie lyk.

Die ontwikkelingsvertraging van veral die skedel en gesig was een van die belangrikste anatomiese veranderinge wat tot die vroeë mens se lewenswyse gelei het. Die meer geronde kop pas baie beter op 'n regop liggaam as die verlengde kop van ape. By die meeste soogdiere word die werwelkolom min of meer horisontaal gehou en die oë kyk reguit vorentoe of na die kante. By die mens - alhoewel die oë vorentoe kyk word die werwelkolom vertikaal gehou, 'n toestand wat 'n buiging van $90^{\circ}$ van die skedel verg. So 'n kromming bestaan by soogdierembrio's, maar kom nie by volwassenes voor nie; by die mens word die embrioniese toestand egter in die volwassene behou.

'n Ander belangrike aspek van die onvolledige ontwikkeling van die skedel en brein by geboorte is dat dit die moontlikheid skep dat die leerproses kan plaasvind terwyl die brein nog besig is om te ontwikkel; sodoende word die proses baie meer vatbaar gemaak vir buitestimulusse as wat by ape en ander diere moontlik is. Daarbenewens maak die algemene retardasie van die res van die mensliggaam die baba byna hulpeloos vir weke of maande na geboorte; dit versterk egter die bande tussen ouers en kinders wat ' $n$ belangrike rol in kultuuroordrag speel.

Ten opsigte van die embrionale en nageboortelike ontwikkeling is daar ook verskille. Swangerskap duur by die mens 'n paar dae langer as by sjimpansees, maar 'n sjimpanseekleintjie kry sy eerste tande wanneer hy minder as drie maande oud is, terwyl 'n mensbaba gewoonlik eers na ongeveer ses maande begin tande kry. Die sagte haarbedekking van pasgebore babas stem ooreen met die hare van embrio-ape wat voor geboorte verlore gaan. Gorillas is op ses- of sewe-jarige ouderdom reeds geslagsryp, maar by die mens geskied dit na 13 tot 15 jaar. 
'n Interessante aspek ten opsigte van 'n skynbaar afwykende anatomiese kenmerk by die mens is dat die ken die uitsondering op die reel is wat neotenie betref want dit is relatief groot terwyl sowel klein as volwasse ape kenloos is. Dit word egter verklaar deur die feit dat daar twee groeigebiede in die onderkaak is, naamlik die dentaalveld wat die beenstruktuur van die kaak is, en die alveolère veld waarin die tande geset word. Beide hierdie velde toon neotenie; hulle het albei klein geword in die menslike evolusielyn. Die alveolère veld het effens vinniger gekrimp as die dentale veld, met die gevolg dat die "ken" slegs verskyn as 'n uitvloeisel van die relatiewe regressietempo's van die twee groeigebiede (Lewontin, 1978).

\section{BREINFUNKSIES}

Die verskil in breinstruktuur en -funksie tussen die mens en ander primate is beslis nie slegs kwantitatief nie. Veranderinge in organisasie, chemiese samestelling, ontwikkelingsfases en in tyd en duur van kritieke tydperke, is slegs 'n paar van die opvallende verskille (Pribram, 1977). Die brein toon 'n hoë mate van lateralisasie, dit wil sè 'n gegewe funksie word verkieslik beheer deur een kant van die brein. Sommige van die funksies wat blykbaar gelateraliseer is, is handigheid, taal, gesigherkenning, gesiguitdrukkings, visuele vaardighede, spontane sywaartse oogblikke, sekere musiekvermoëns, depressie, euforie, ensovoorts (Falk, 1987). Die literatuur oor lateralisasie is kompleks en bevat baie skynbare teenstrydighede, maar dit kan moontlik aan metodologiese of teoretiese verskille toegeskryf word.

Die vermoë van die mens om die toekoms te antisipeer en om die verband tussen middel en doel te sien, is onteenseglik aan die bestaan van 'n groot en komplekse brein gekoppel. Hierdie vermoë om aksies te beplan waarvoor daar eers in die verre toekoms belonings sal kom, is 'n tipe vertraagde respons wat sosioloë die 'uitstel van beloning' noem. Vir al hierdie funksies word die brein tydens 'n lang kinderjaretydperk voorberei; tydens hierdie tydperk moet jong kinders taal verwerf, werktuie makk en gebruik, en komplekse gewoontes, reëls en inligting verwerk en baasraak. 
Die brein is die kultuurorgaan en kultuur is die funksie van die brein (lsaac, 1983). Die term kultuur verwys na aspekte soos taal, vaardighede, sosiale gebruike, tradisies en inligting wat mettertyd bekom word. Hierdie tipe kulturele kompleksiteit en soepelheid is onbekend by enige ander organisme en sal buitendien onmoontlik wees sonder die menstipebrein; laasgenoemde vereis, op sy beurt, 'n verlengde kindweestydperk en 'n hoë gehalte voeding (Lewin, 1982). Die brein is dan ook - ten opsigte van gedrag - die mees fundamentele anatomiese kenmerk van die mens, want dit het die ontwikkeling van tegnologie en kultuur moontlik gemaak.

Die vermoë van die mensbrein ten opsigte van simboliese kommunikasie (taal) is by verre beter as die van die gesofistikeerdste rekenaarprogram, en dit weerspieël sy eie merkwaardige gespesialiseerde eienskappe. Taatvermoë is veral gekoppel aan twee streke van die temporaallob van die serebraalkorteks (Geschwind, 1970; Kimura, 1973; Galaburda et al., 1978). Die ontwikkeling van hierdie twee areas, die een wat verbale uitsette beheer en die ander wat begrip en boodskapinhoud reguleer, vind by byna alle mense plaas en is warskynlik deel van neurale stelsels wat taalleervermoë aanhelp; indien dit so is behoort diere dus nie in staat te wees om ' $n$ taal te kan leer nie. Hierdie hipotese kan getoets word aan beskikbare resultate van eksperimente waarin gepoog is om taal aan ape te leer (Premack, 1971; Premack $\varepsilon$ Premack, 1972; Rumbach $\varepsilon$ Gill, 1976; Rumbach, 1977).

Volgens Penfield $\varepsilon$ Roberts (1959) is die dele van die korteks wat met die bron van spraaksimbole en -konsepte te make het, meestal in die sogenaamde dominante hemisfeer (gewoonlik die linkerkant) geleë. By die moderne mens bestaan daar 'n hoë negatiewe korrelasie tussen die kant van die dominante hemisfeer en links-en regshandigheid. Die meeste mense is regshandig en het linker serebrale dominansie, terwyl minstens die helfte van linkshandige mense regter serebrale dominansie het. ' $n$ Klein mate van linksheid of regsheid kom wel by ape voor, maar hierdie hemisfeerdominansie met 'n voorkeurgebruik van ledemate is 'n kenmerk wat slegs by die mens in 'n hoë mate voorkom. Dit is ook interessant dat dit nie reeds by jong babas voorkom nie, maar mettertyd ontwikkel en saamhang met die ontwikkeling van spraak vanaf die tweede tot die twaalfde jaar. Spraak en skryfvermoë is unieke korrelate van $-100-$ 
die dominante hemisfeer en spraak is noodsaaklik om uitdrukking aan bewustheid te gee. Dit wil nie sè dat bewustheid nie ook van die nieverbale hemisfeer kenmerkend is nie, al kan dit nie geverbaliseer word nie. Die mens is beslis terdeë bewus van homself ten opsigte van sy relasie tot sy omgewing, sonder die hulp van verhaalsimboliese denke.

Die grootte van die brein, wat by die moderne mens van 1000-2000 cc kan wees is $n$ belangrike aspek van linguistiese vermoë. 'n Groot brein is egter nie 'n noodsaaklike korrelaat van spraakvermoë nie. Terwyl die olifant en walvis 'n groot brein het, het hulle geen taal nie, maar sekere mensdwergies met breine wat niks groter as die van gorillas is nie (400-600 cc) kan op die vlak van $n$ kind van vyf jaar praat ondat hulle die anatomiese korrelate van taal besit. Al het ape ' $n$ skedelvolume van tot $700 \mathrm{cc}$ het hulle nie die vermoë om soos mense te kan praat nie (kyk later).

Simboliese kommunikasie

'n Simbool is ' $n$ voorwerp of handeling waarvan die betekenis nie vanselfsprekend is nie, maar eerder iets waaroor ooreengekom is deur diegene wat dit gebruik of toepas. 'n Teken, daarenteen, is iets waarvan die betekenis sommer duidelik is sonder dat dit aan ' $n$ ooreenkoms binne ' $n$ gemeenskap gekoppel is. So, byvoorbeeld, kan huil 'n teken van pyn wees, maar die woord 'huil' is ' $n$ simbool vir huil slegs omdat die mense vroeër stilswyend ooreengekom het dat dit so moet wees. Die mens en diere kommunikeer deur middel van tekens, maar slegs mense kommunikeer met behulp van simbole. (Volgens die kultuurteorie van Krebs \& Dawkins (1984) behoort tekens by diere nie as kommunikasie beskou te word nie, maar eerder as manipulasie, want spesiegenote word slegs deur die tekens geaktiveer om te reageer.) Die tale van die mens is simbolies, terwyl die sogenaamde dieretale eerder uit tekens as simbole bestaan. Sjimpansees en miskien sekere ander diere kan wel die betekenis van simbole leer en dit in kommunikasie gebruik. maar hulle vermoë in hierdie verband is baie beperk. Wat sekerlik waar is, is dat diere nie simbole skep en hulle dan in gewone kommunikasie gebruik nie - in elk geval nie op so 'n vlak dat 'n mens dit kan agterkom nie. 
Een of ander vorm van kommunikasie kom altyd by geslagtelik voortplantende diere voor omdat dit noodsaaklik is om die twee geslagte by mekaar te bring. Maar dit is veral by sosiale diere waar kommunikasie as 'n uiters belangrike aanpassing voorkom, want gemeenskappe is vir hulle bestaan van die kommunikasie tussen individue afhanklik. Sosiale gedrag en organisasie mak staat op en ontstaan uit hierdie verskynsel; dit is die wyse waarop een organisme 'n reaksie by 'n ander aan die gang kan sit. Kommunikasie by sosiale organismes is so belangrik dat die sosiale wetenskappe al gedefinieer is as die studie van die kommunikasiewyses binne sosiale groepe. By alle diere is hierdie wyses nie-verbaal; slegs by die mens het ' $n$ taal ontwikkel om nie-verbale tekens aan te vul.

Kommunikasie by hoër diere bestaan hoofsaaklik uit die uitruiling van 'n beperkte repertorium van tekens wat oorgeërf is en relatief onveranderlik binne ' $n$ spesie is. Byna al hierdie tekens het met heersende omstandighede te make en is "uitinge" wat eenvoudig, dringend en direk is. By die hoër primate word verskeie kommunikasiekanale benut, maar, in vergelyking met laer diere, verskuif die klem van olfaktoriese na visuele reseptore. Olfaktoriese tekens bly egter nog belangrik, veral by seksuele ontmoetings waar kennis van die estrustoestand van die wyfie deur middel van feromone na die mannetjie oorgedra word, en om die onderlinge band tussen moeder en suigeling te verstewig. Visuele tekens wissel van die onwillekeurige fisiologiese kleuring van geslagsdele by wyfies (wat estrus aandui) tot die gesigsuitdrukkings, gebare en vertoon wat so algemeen by bobbejane en sjimpansees waargeneem word. Gesigsuitdrukking - wat duidelik sigbaar is by ' $n$ relatief haarvrye gesig - is hoogs ontwikkel by sjimpansees en die mens. (Dit is interessant dat mans met $n$ volbaard hierdie kommunikasiekanaal waarskynlik in ' mindere mate as sjimpansees gebruik.) Lyftaal is ook belangrik by hoër primate en die mens, maar is nie altyd so opvallend in menskultuur nie. Aanraking as kommunikasiewyse speel veral ' $n$ belangrike rol in die opbou van verhoudings tussen verskillende geslagte en tussen moeder en kind. By die mens is vokale kommunikasie egter beslis die belangrikste kanaal.

Funksies en aard van tekens. Die funksies van vokaliserings en ander kommunikasietekens by hoër primate kan in vier hoofgroepe ingedeel word (Campbell, 1976): Eerstens is daar tekens wat saambinding tussen $-102-$ 
moeder en kind, of binne 'n sosiale groep as geheel, bewerkstellig. Tweedens hou sekere tekens verband met territoriale afbakening en verdediging van 'n tuisgebied. 'n Derde tekentipe is die wat die beskikbaarheid van voedsel aandui, en 'n vierde tipe is alarmroepe wat met die waarneming van predatore gepaard gaan. Die meeste primate beperk hulle tekens tot items 1,3 en 4 en in ' $n$ sosiale groep sal die meeste kommunikasies in die eerste kategorie wees.

Die tipe bewustelike bedoelings wat met die mens se verbale kommunikasie gepaard gaan, moet egter nie ook aan diere toegeskryf word nie. Bogenoemde tekens word gegenereer of gemotiveer deur die verskynsel van emosie, met 'n neurologiese oorsprong in die limbiese stelsel van die brein (dit wil sê nie in die korteks nie, maar hoofsaaklik in die rinenkefalon). Deur emosie op stereotipe en uiterlik waarneembare wyses te toon, lig diere mekaar in ten opsigte van hulle behoeftes en vrese en dit sit paslike response aan die gang. Uiting van emosies is die grondslag van sosiale lewe; dit skep en handhaaf onderlinge bande en struktuur in die gemeenskap. Nie-verbale kommunikasie vind dus plaas deur die uiting van emosies en deur die bewustheid van die gedrag van ander.

Alhoewel 'n roepstelsel en 'n taal beide vokaal-ouditoriese kommunikasiewyses is, verskil hulle heeltemal van mekaar. Sjimpansees kan geleer word om simbole op 'n min of meer linguistiese wyse te gebruik (Gardner \& Gardner, 1978; Premack \& Premack, 1972), maar omdat hierdie gedrag van menshulp afhanklik is en dit basies gebare is, impliseer dit nie dat die sjimpansee self ' $n$ beperkte linguistiese vermoë het wat met diè van die mens vergelyk kan word nie. Hockett E Ascher (1964) het aangetoon dat daar betekenisvolle verskille is tussen vokalisasies en taal. Hierdie verskille is die volgende:

1. Verskillende roepe is onverenigbaar, dit wil sè 'n dier kan nie 'n komplekse dubbelroep voortbring met sekere eienskappe van een roeptipe en sekeres van 'n ander roeptipe nie. Slegs een roep kan op 'n slag uitgestuur word. Dit staan bekend as "geslote", terwyl 'n taal daarenteen "oop" is in die sin dat ons vryelik enige samestelling van klanke kan voortbring. 
2. 'n Roep word slegs in die aanwesigheid van die gepaste stimulus uitgestuur; 'n roepstelsel toon geen tyd- of ruimteverplasing nie. Spraak, daarenteen, toon dit wel; ons praat vryelik van dinge wat buite sig is, in die verlede of toekoms is, of selfs glad nie bestaan nie. Hierdie vermoë van spraak is op gedagteprosesse gebaseer.

3. Daar bestaan ' $n$ algehele verskil tussen die klanke van enige twee roepe. Spraak, daarenteen, is die uitbouing van 'n beperkte aantal klankkomponente wat op sigself geen betekenis het nie, maar, volgens hulle patroon, 'n oneindige aantal betekenisse kan hè.

4. Die roepstelsel is angebore (gegenereer deur die limbiese stelsel) en die verhouding tussen stimulus en respons is dus geneties bepaal; dit kan nie maklik gewysig word nie. Taal daarenteen, word aangeleer (gegenereer deur die korteks) en die oordra daarvan moet afhang van die mens se vermoë om te memoriseer en te vokaliseer. Die praatvermoë is egter ' $n$ genetiese aanleg, want geen poging om 'n nie-mens te leer praat sal slaag nie.

Taal en praatvermö̈. Die taal van die mens het sowel 'n tyd- as 'n ruimtedimensie. Dit hoef nie slegs op heersende omstandighede betrekking te hè nie, maar daar kan ook na tye van die verlede en die toekoms, en na afgeleë plekke verwys word. Die vermoë om 'n taal te gebruik is een van die mens se belangrikste ekstrasomatiese aanpassingskenmerke, en is sekerlik net so oud soos die vermoë ten opsigte van kultuuraktiwiteite. Trouens, dit word aanvaar dat die twee saam ontwikkel het deur 'n proses waarin die maak en gebruik van werktuie, kommunikasie en koöperasie, abstrakte denke en vindingrykheid almal op 'n onderling afhanklike wyse met mekaar geskakel het (Campbell, 1976).

Tydens die praataksie word 'n stel liggaamsdele in werking gestel waarvan die primère funksies filogeneties heeltemal anders was. Die larinks, tong en lippe is vir hierdie taak sekondèr oorgeneem sonder enige noemenswaardige wysigings en sonder belemmering van hulle primère funksies. Die belangrikste fisiese menskenmerk is die aanwesigheid van die farinks as 'n kort ruimte tussen die epiglottis en die sagteverhemelte; dit is die buis wat die tipiese resonante fonering (artikulasie van klanke) by die mens moontlik maak. Die verskil tussen die mens en ape is nie in die -104 - 
mens se vermoë om geluide te mak geleë nie, maar in die tipes geluide wat voortgebring word en die merkwaardige wyse waarop resonante note met die konsonante van spraak onderbreek word. Die feit dat die tong naby die larinks en sykante van die mond is, maak dit moontlik om, benewens die gewone vorming van konsonante, by sommige tale ook keelklanke ( gutturale) en klikgeluide te maak.

Die relatief lang, gebuigde farinks wat eie is aan die moderne mens, is nie in pasgebore babas, ape of selfs Australopithecus aanwesig nie. Die funksionele klankkanaal van die moderne mens ontwikkel gedurende die tweede lewensjaar. 'n Kort aapagtige farinks (soos by babas en individue met Downsindroom) beperk die verskeidenheid vokaalklanke en die konsonante en verander die spraakmoontlikhede in baie ander opsigte (Lieberman et al., 1972).

Volgens Andrew (1965) toon bobbejane ons hoe die spraakvermoë kon ontstaan het. Lipklappery is ' $n$ algemene kommunikasievorm by bobbejane - 'n aksie wat voortspruit uit die bewegings van die lippe en tong tydens die liggamsversorgingsproses. By hoër primate kom lipklappery ook dikwels as 'n groet voor, mar slegs by bobbejane gaan dit met 'n gromgeluid gepard. Hierdie knorre wat deur die tong- en lipbewegings gereguleer word, klink baie soos mensvokale en word ook presies op dieselfde wyse voortgebring. Dit moet egter in gedagte gehou word dat spraak baie meer kompleks as geluide is. Dit is die handeling van kodifiserende denke in stelle beheerde en samehangende klanke, en hierdie kodifisering vind in die serebraalkorteks plaas. Die primère motoriese area vir spraak - wat beweging van die lippe, tong, ensovoorts beheer - is in die motoriese girus geleë. Tydens die praat- en skryfproses moet impulse vanaf hierdie area langs die verskillende senuwees na die spraakapparaat of hand gaan. Die gevolglike bewegings van die spraakapparaatmuskulatuur in vokalisasie en die presiese beweging van die hand tydens die skryfproses is gekondisioneerde reflekse. Die motoriese girus het self egter niks met assosiërende woorde en konsepte te make nie.

Taal het die geweldige omvang van kultuurontwikkeling moontlik gemaak en dit het aan die mens unieke mensselfbewustheid en die bewustheid van ander wesens verskaf. Al die getuienis dui sterk daarop dat taal 'n $-105-$ 
geneties bepaalde kenmerk van die moderne mens is. Die verskillende tale wat gepraat word, die werklike woorde wat gebruik word, is deel van die kultuur. Maar hierdie merkwaardige en unieke tipe mensgedrag berus op in gawe wat van die Skepper ontvang is: om met behulp van 'n groot brein wat stadig tot volwassenheid ontwikkel, te kan leer om te praat.

Taaloorsprong. By 'n simposium oor die oorsprong en spreiding van moderne mense wat in Maart 1987 te Cambridge, Engeland, gehou is, is onder andere menings uitgespreek oor die praatvermoë van die mensvoorvaders (Lewin, 1987). Harold Bibble, 'n antropoloog van die Universiteit van Pennsylvania, het tot die gevolgtrekking gekom dat die bestaande getuienis van klipwerktuigtegnologie van prehistoriese hominiede nie enige aanduiding gee dat hulle kon praat nie. Die enigste werklike getuienis van taalvermoëns is te vind in die anatomie van die moderne mens se stemkanaal wat veral in twee opsigte belangrik is. Die eerste is dat dit goed toegerus is vir die produksie van 'n reeks nienasale vokaalklanke wat die presisie en tempo van data-oordrag deur middel van spraak bevorder. Die tweede is in verhoging van die waarskynlikheid van verstikking. Laasgenoemde is seker die ontwikkelingsprys wat vir eersgenoemde betaal word.

Die larinks van die mens - eintlik die supralaringeale vokaalkanaal - is in 'n baie hoë mate op die een funksie van komplekse spraak ingestel. Volgens Philip Lieberman van die Brown-universiteit in die VSA dui fossielgetuienis daarop dat die anatomiese en neurale stelsels vir spraak in sekere hominiedstamlyn oor die afgelope 500000 jaar ontwikkel het. Die afrondingswerk van hierdie stelsel - wat vokaalproduksie en die verstikgevaar bevorder het - sou dan met die aankoms van die moderne mens binne die afgelope 100000 jaar geskied het.

Die konstruksie van die praattoerusting van die mens het gepaard gegaan met 'n vergroting van die stemorgaan, enersyds deur die omstandigheid dat die larinks dieper in die nek ingesak het, en andersyds deurdat die verhemelte as gevolg van 'n opwaartse fleksie van die skedelbasis verskuif het. Die bou van die tong wat, anders as by die ander primate, gerond is en tot in die farinks strek, is van besondere belang vir die fyn manipulering van klanke. Die vermoë om die lugweg na die longe $-106-$ 
tydens die slukproses af te sluit, en die sluiting van die neusgang om sekere vokale te vorm, mak suiwere kommunikasıe moontlık.

'n Aantal jare gelede het Lieberman en sy kollegas die stemapparaat van Neanderdalmense (wat voor die moderne mens geleef het) ontleed en anatomiese beperkings vasgestel ten opsigte van die omvang van spraakgeluide wat voortgebring kan word. By hierdie mense was die larinks hoog in die nek en die tong was byna heeltemal binne-in die mondholte sodat dit nie 'n belangrike deel van die wand van die farinks gevorm het nie. Volgens Lieberman kon die Neanderdalmens se stemkanaal inherent nie sekere vokale voortbring nie en die uitsette was genasaliseer wat tot hoër fonetiese foute sou gelei het. Hierdie interpretasie is egter deur verskeie outeurs betwis en hulle is weer van mening dat Neanderdalers 'n volle omvang van spraakklanke kon beheers. Lieberman beweer egter dat dit maklik bewys kan word dat so 'n opvatting verkeerd is. Byvoorbeeld, as die geronde tong van die moderne mens in die verlengde mondholte van 'n Neanderdaler geplaas sou word, sal dit die larinks tot onder die vlak van die nekwerwels afdruk. So 'n rekonstruksie skep 'n onmoontlike wese; geen soogdier het 'n larinks in sy bors nie. Aanpassings aan mondasemhaling en verskillende koupatrone het waarskynlik 'n invloed uitgeoefen op die basiese anatomie wat met spraak te doen het, maar die finale herstrukturering van die supralaringeale vokaalkanaal het as gevolg van fonetiese oorwegings tot stand gekom, aldus Lieberman. Baie antropoloë sien hierdie finale stap as dié sleutelelement wat vir Homo sapiens die moontlikhede geskep het om hom uniek te maak.

\section{EKSPERIMENTE MET APE}

Gedurende veral die vyftiger- tot sewentigeriare het in hele aantal eksperimenteerders die moontlikheid dat jong ape die mens se taal kan leer, ondersoek (Marx, 1980; Wade, 1980; Savage-Rumbach et al., 1980; Ferry, 1984; Alcock, 1984). Die eerste van hierdie pogings was die van twee psigoloë Keith en Catherine Hayes wat 'n jong wyfiesjimpanzee (Viki) in hulle huis grootgemaak het tot op 'n ouderdom van $61 / 2$ jaar. Ten spyte daarvan dat sy soos 'n menskind behandel is en ten spyte van enorme pogings deur Catherine Hayes, het Viki nooit geleer om meer as drie or vier woorde te uiter nie. Maar sy het tog geleer om op in hele -107 - 
aantal woorde te reageer; sy het in sommige opsigte soos 'n menskind opgetree, en dit het selfs voorgekom of sy met ' $n$ denkbeeldige trekspeelding speel (Hayes, 1951). Al kon die sjimpansee baie van die mens se handelinge leer, was dit egter duidelik dat vokale, geartikuleerde taal heeltemal bo haar vuurmaakplek was.

'n Suksesvoller eksperiment is deur R.A. en B.T. Gardner (1969; 1975; 1978) met 'n babawyfiesjimpanzee (Washoe) uitgevoer. Hulle het nie gepoog om aan Washoe 'n gesproke taal te leer nie, maar eerder die Amerikaanse "vingertaal" vir dowes (Ameslan of ASL) wat uit konvensionele verteenwoordigende tekens bestaan en nie 'n handvoorstelling van Engels is nie. Op hierdie wyse kon die sjimpansee 'n heel indrukwekkende "woordeskat" van tekens bemeester. Kortland (1973), wat ook waarnemings by Washoe gemaak het, kom tot die gevolgtrekking dat ape baie minder te sé het as wat hulle kan dink.

'n Ander ondersoekbenadering is diè van Premack (1976a, b) wat plastiekskyfies gebruik het om woorde voor te stel terwyl hy met die sjimpansee gepraat het. Die diere het mettertyd ' $n$ groot woordeskat opgebou en kon soms die skyfies rangskik om frases te vorm; hulle kon, volgens Premack, selfs in 'n mate stellings aangaande dinge wat nie aanwesig is nie verstaan.

'n Vierde studie wat by Yerkes Primate Center met 'n sjimpansee, Lana, uitgevoer is, behels "n spesiaal ontwerpte "taal" - bekend as Yerkish wat aan die dier geleer is (Rumbaugh $\varepsilon$ Gill, 1976; Rumbaugh, 1977); in hierdie sisteem het Lana sinne saamgestel deur knoppies op in rekenaar te druk om tussen ' $n$ beperkte aantal tekens 'n keuse te maak.

Uit die resultate van bogenoemde eksperimente kan afgelei word dat dit moontlik is om elemente van ' $n$ menslike kommunikasiekode aan jong ape te leer en dat hulle leervermoë groter is as wat vroeëre waarnemings aangedui het. Die gevaar is egter geleë in gevolgtrekkings wat hieruit gemaak word en 'n mens kan heelhartig saamstem met die stellings van Jerison (1975): "One often underestimates the capacity of animals to learn and to perform complex tasks. The effect of the study of animal language, in my judgment, is to force linguists to define language more precisely, rather than to demonstrate language' in chimpanzees. We -108 - 
must, afterall, know what it is we are trying to demonstrate." Wat Washoe betref, is dit duidelik dat twee van die kenmerkende eienskappe van taal in Ameslan ontbreek: die vokaal-ouditoriese kanaal en dualiteit van patronering. Nóg Washoe nóg enige van die ander sjimpansees in ondersoeke het enige tekens getoon dat hulle die vermoë het om hierdie eienskappe te kan hanteer. Hayes kon Viki nie leer om te praat nie, en die tekens wat Washoe, Premack se Sarah, en Rumbaugh se Lana geleer is, is volledige eenhede wat nie verder in samestellende dele afgebreek kan word soos dit in die geval van menswoorde, of morfeme, is nie (Bourguignon, 1976).

'n Belangrike aspek wat in gedagte gehou moet word, is die onderskeid wat bestaan tussen ' $n$ dier se potensiaal ten opsigte van sekere gedrag in die ekologiese nis van die mens, en sy gedrag wat aangeleer of vrygelaat word in sy eie ekologiese tuisgebied en sosiale opset. Om te illustreer: Washoe kon ASL aanleer met behulp van haar mensinstrukteurs, maar in daardie hele menslike opset waarin sy moes funksioneer, het sy nie haar vermoë om soos wilde sjimpansees selfversorgend te wees, ontwikkel nie. Dit kom dus daarop neer dat ape soms die vermoë het om twee dinge te leer, maar hulle kan dit nie gelyktydig baasraak nie; dit is iets wat die mens met die grootste gemak kan doen.

Dat ape ook nie in stat is om sinne te skep nie, is onteenseglik deur Terrace et al. (1979) bewys. Net soos die Gardners het hierdie outeurs 'n sjimpansee ( $\mathrm{Nim}$ ) soos $n$ kind grootgemaak en kommunikasie ten opsigte van alle daaglikse gebeure probeer aanmoedig. Nim is ' $n$ tekentaal geleer en video-opnames is van die leerproses en resultate gemaak. $\mathrm{Na}$ 'n aantal jare het Terrace en sy kollegas tot die volgende gevolgtrekking gekom: Projekte ten opsigte van pogings om sjimpansees en gorillas ' $n$ taal te leer gebruik, het getoon dat hierdie ape 'woordeskatte' van visuele simbole kan leer. Daar is egter geen getuienis dat ape sulke simbole kan kombineer om nuwe betekenisse te skep nie. Die funksie van die simbole van ' $n$ aap se 'woordeskat' is blykbaar nie om dinge te identifiseer of om inligting oor te dra nie, maar eerder om die simbool te gebruik om 'n beloning te ontvang. Nim se gebruik van tekentaal verskil basies van die van ' $n$ kind en hy was baie minder kreatief as ' $n$ kind in die voortbrenging van geluide. Daar is ook geen aanduiding dat 'n aap se -109 - 
multitekenuitinge as 'n sin beskou kan word nie (Marx, 1980). Ape kan baie geïsoleerde simbole leer, maar hulle toon geen vermoë om die gespreks-, semantiese of sintaktiese organisasie van taal baas te raak nie.

KOMMUNIKASIE EN KULTUURGEDRAG

Deur die eeue is van diere as studievoorwerpe gebruik gemaak om verskynsels by die mens te probeer verklaar (Ryke, 1987c). Die etologiese werk van die Nobelpryswenner Konrad Lorenz (1935) laat mense tans nog soek na coreenkomste tussen eende, tiers en die mens, en dieselfde geld vir B.F. Skinner (1938) se psigologiese werk op duiwe en rotte. Diere vertel ons wel heelwat van die mens, maar hulle kan ons nie naastenby alles vertel nie. Soos Bronowski (1973) dit uitdruk: "There must be something unique about man because otherwise, evidently, the ducks would be lecturing about Konrad Lorenz, and the rats would be writing papers about B.F. Skinner. Let us not beat about the bush. The horse and the rider have many anatomical features in common. But it is the human creature that rides the horse, and not the other way about. And the rider is a very good example, because man was not created to ride the horse. The plasticity of human behaviour makes that possible." Die mens is nie uniek omdat hy wetenskap of kuns as sodanig beoefen nie, maar omdat sowel wetenskap as kuns uitdrukkings is van sy wonderbaarlike intellek en geestesplastisiteit.

in Groot verskil tussen kommunikasie by diere en by mense is dat by diere slegs sekere dinge aan spesiegenote (of natuurlike vyande) oorgedra kan word, maar hulle kan nie vrae vra en antwoorde daarop kry nie; by die mens bestaan daar ' $n$ uitruiling van gedagtes wat, sover ons kennis strek, slegs deur middel van 'n taal moontlik is. Die betekenis van die relasie tussen die drie faktore - brein, taal en kultuur - moenie onderskat word nie, want biologies is kultuur die produk van neurale masjinerie. Kultuurpraktyke is aangeleerde gedragspatrone wat van een generasie na die volgende deur tradisie (leerproses) oorgedra word en dit word moontlik gemak deur die feit dat jeugdige mense breine het wat die tradisie-inligting kan berg; in hierdie verband speel hoëgehaltevoeding 'n belangrike rol. 
Hoëgehaltevoeding wat noodsaaklik is vir die komplekse mensbrein, hang saam met 'n ander reeks unieke gedragskenmerke van die mens: Die kollektiewe verkryging van voedsel, die uitstel van die verbruik daarvan, die vervoer van die voedsel na 'n ander plek, en die gemeenskaplike verorbering by in tuisbasis of sentrale plek. Hierdie kenmerke is so basies in die mens se lewe dat ons dit as vanselfsprekend aanvaar, maar dit is ' $n$ hemelsbreë gedragsverskil in vergelyking met ape. In hierdie verband stel Isaac (1983) die saak so: " ... if we could interview a chimpanzee about the behavioural differences separating us, this might well be the item that it found most impressive - "These humans get food and instead of eating it promptly like any sensible ape, they haul it off and share it with others." Tradisie en kommunikasie deur middel van taal vervul hier ook 'n belangrike rol om inligting te verskaf.

Die vermoë tot simboliese transformasie van ondervinding lè die kenmerkende eienskappe van taalkommunikasie ten grondslag. Die vermoë van mense om deur middel van taal sekere dinge met hulle medemense te deel is uniek ondat dit private, interne of intrinsieke prosesse soos subjektiewe voorstellings van ondervindings, verbeeldingsvlugte en drome insluit. Hierdie mededeelsaamheid word moontlik gemaak deur ekstrinsieke simbolisme, dit wil sè wyses waarop ondervindings 'n vorm gegee kan word wat buite hierdie ervarings is en wat nie daarmee verband hou nie (Bourguinon, 1976). Taal is natuurlik die primére voorbeeld van so 'n simboliese stelsel, terwyl die visuele kunste, danse en rituele voorbeelde van nie-linguistiese ekstrinsieke simboolstelsels is. Omdat mense in mekaar se belewenisse kan deel, word hierdie ervarings ook deur groepprosesse beĩnvloed en gewysig. Prosesse, soos geheue of drome, bestaan beslis ook by baie diere, maar omdat hulle ekstrinsieke simbolisme ontbeer, bly daardie prosesse privaat en word dit nie blootgestel aan die invloed van onderlinge uitruiling van ervaringsgegewens, groepaandrange en tradisies nie. In teenstelling hiermee, word daar in baie mensgemeenskappe, byvoorbeeld, ernstige aandag aan drome gegee; omdat hulle oorvertel, bespreek, geëvalueer en geïnterpreteer word, lyk dit of hulle aard in ' $n$ hoë mate kultuurgebonde is

Volgens Hallowell (1960) word die kultuur van die moderne mens, wat voortvloei uit die komplekse, gedeelde simboliese stelsels, deur die universele bestaan van selfbewussyn en 'n normatiewe oriëntasie gekenmerk. 
In teenstelling met die sosiale lewe van diere, is elke sosiale orde by die mens ook 'n sedeorde. ledere gemeenskap het sy norme van reg en verkeerd, en elk het sy stelsel van sosiale beheer. Sosiale gedragsreëls wissel van die wat moord en bloedskande verbied tot die wat voorskriftelik is ten opsigte van wat geëet mag word, eiendomsreg, onderlinge gesinsgedrag en selfs etiket; misdaad en sonde is kenmerkende menslike verskynsels. In hierdie verbande is dit belangrik dat die mens ' $n$ individuele gewete en selfoordeelsvermoë het, wat ' $n$ voorvereiste vir moraliteit is. Hierdie identiteitsin impliseer selfagting en trots, maar ook skuldgevoel, skaamte en angs. Dit is eintlik soms ' $n$ skok om te besef dat geregtigheid ook deel is van die biologiese toerusting van die mens. Al hierdie vermoëns kan slegs met behulp van taal ontwikkel en tot uiting kom. As individue leer die mens om homself te takseer teen die agtergrond van 'n sosiaal-gesanksioneerde en geïnternaliseerde sedekode.

Dat daar in bogenoemde kommunikasie- en kultuuraspekte sekere ooreenkomste tussen mense en ape is, val nie te betwyfel nie, maar daar is 'n radikale innovasie betreffende die ontwikkeling en rol van kultuur by die mens (Hallowell, 1960). In hierdie verband kan met Bourguignon saamgestem word waar hy Hallowell se siening evalueer: "He avoided the twofold trap that awaits the unwary who venture into this terrain; either to see human beings as apes with a little more (or a little less) - the naked ape, the talking ape - or else to see apes as incomplete humans similar to human children or slightly retarded adults." In hierdie verband is dit ook belangrik om op te merk dat mense en diere dinge kan leer, maar slegs die mens kan iets wat hy geleer het uit vrye wil afleer.

\section{TAALLEERVERMOE}

Die vraag hoe dit moontlik is dat ' $n$ jong kind vinnig en sonder moeite kan leer om te praat en te verstaan het in die laaste aantal jare besondere aandag gekry. Resente ontdekkings dui daarop dat die brein van 'n baba eienskappe het wat die leer van 'n taal vergemaklik (Eimas, 1975, 1985; Poizner et al., 1987). Spesifieke perseptuele meganismes wat betrokke is in die subtiele diskriminasie van spraakklanke is blykbaar reeds by geboorte in die bababrein aanwesig. Kort na geboorte gaan alle babas deur ' $n$ brabbeltaalstadium waartydens hulle 'n verskeidenheid ongestruktureerde klanke voortbring; dit hou warskynlik verband met taal$-112-$ 
geluide wat hulle gehoor en in hulle geheues geberg het (Lenneberg, 1968). Woordeskatontwikkeling geskied merkwaardig vinnig by kinders met normale gehoor. Teen 18 maande het die gemiddelde kind reeds beheer oor 50 woorde. Net ' $n$ anderhalfjaar later sal die kleuter in staat wees om ongeveer 1000 woorde te gebruik en baie meer te verstaan; dit lyk, trouens, of 'n driejarige kind alles wat aan hom gesè word kan begryp. Hierdie vermoë om tientalle woorde binne kort tydperke te prosesseer en om hulle simboliese inhoud te verstaan, is 'n merkwaardige kenmerk wat eie aan die mens is.

In teenstelling met die leerproses van lees en reken, bemeester 'n kind taal sonder enige formele onderrig; trouens, heelwat van die taalleerproses vind plaas binne 'n redelik beperkte linguistiese omgewing, waar geen spesifieke reëls ten opsigte van taalvaardigheid ter sprake is nie. Die vinnige taalbemeestering kan egter nie aan die eenvoudigheid van die proses gekoppel word nie. Navorsing gedurende die afgelope aantal dekades oor die aard, produksie en verstaanproses van taal, het aangedui dat eenvoud nie hier ter sprake is nie, maar eerder toenemende kompleksiteit. Daar moet dus aangebore kennis en vermoëns wees wat onderliggend aan taalgebruik is; dit was ook reeds voor 1972 die siening van Chomsky. Hierdie aangebore persepsiemeganismes word dramaties gedemonstreer wanneer die baba begin om sy ouers se taal te leer. Dit is moontlik dat net soos in die geval van die gespesialiseerde anatomie van die vokaalkanaal en spraaksenters in die brein, hierdie perseptuele vermoëns spesifiek vir die persepsie en begrip van taal ontwikkel het (Eimas, 1985). Hierdie unieke aanpassing stel die kind in staat om die ouers se taal en kultuur so vroeg moontlik in sy lewe te verwerf. Die doeltreffendheid van hierdie meganismes word weerspieël in die feit dat die kind binne so ' $n$ kort tydjie by die taalgemeenskap aansluit. Dit is dan ook ' $n$ besonder belangrike eienskap vir oorlewing. As ' $n$ kind, byvoorbeeld, tot op dertienjarige ouderdom geen taal leer nie dan is dit byna onmoontlik om daarna hoegenaamd te leer praat. Maar as iemand as jong kind normaalweg ' $n$ taal leer praat, kan hy op ' $n$ later leeftyd enige taal aanleer. Die belangrikste vereiste is dus dat ' $n$ kind taal moet verwerf - dit maak nie saak watter taal nie (Bronowski, 1973).

'n Interessante teorie in verband met die taalleerproses is dat ' $n$ Kreoolse taal die oorspronklike taal van die mens was en dat die aangebore $-113-$ 
taalleermeganismes op so 'n taaltipe toegespits is (Bickerton, 1983). Dit hou in dat Kreoolse tale makliker vir kinders is om te leer en dat alle ander moderne tale ewe maklik of moeilik deur 'n kind aangeleer word. Die vraag is dus hoekom praat alle kleintjies nie Kreools nie? Die antwoord hierop - volgens die teorie - is dat kinders dit wel doen (babataal), maar omdat mense rondom hulle aanhou om Afrikaans, of Engels of Duits, of watter taal ook al te praat, moet die kind die grammatika van die basiese taal wysig totdat dit aan die plaaslike omgangstaal se vereistes voldoen.

As die vermoë van mense en ape ten opsigte van leervermoë vergelyk word, dan is dit dadelik duidelik dat die buitengewone opleidingsprogramme wat nodig is om sjimpansees 'n aantal tekens te leer, glad nie by taallerende kleuters nodig is nie. Mensbabas vind taal op sigself belonend genoeg en het nie gedurig belonings in die vorm van voedsel of ander hulpmiddels nodig vir korrekte vokaliserings nie. Selfs verwaarloosde of mishandelde kinders sal doeltreffende spraak ontwikkel (Alcock, 1984). In hierdie verband is dit betekenisvol dat sommige dowe kinders, wat nie die vermoë het om 'n gesproke taal te leer nie en aan wie nie 'n standaard vingertaal geleer word nie, hulle eie tekentaal ontwikkel wat die grammatiese eienskappe van menstaal toon (Goldin-Meadows \& Feldman, 1977). Die mens se ontwikkelingstelsel is blykbaar so uniek dat dit vir hom moeilik is om nie die vermoë om taal te gebruik te ontwikkel nie. Dit beklemtoon net weer die geweldige belangrikheid van taal - of liewer die praatvermoë - vir die suksesvolle voortbestaan en ontplooiing van Homo sapiens.

\section{HEDE EN TOEKOMS}

As 'n mens 'n terugskouing maak van die unieke eienskappe van die mens dan is dit baie duidelik dat kenmerke wat verband hou met die brein uittroon, want dit bepaal in 'n hoë mate die verstand, die gees, die gedagtewèreld en alles wat daarmee saamhang. Die brein is egter ook maar 'n orgaan, soos die hart, die nier of die lewer en ons weet dat organe onklaar kan raak as gevolg van sowel erflikheids- as omgewingsfaktore. Vir baie mense is die brein egter meer as net ' $n$ orgaan: Dit is die sentrum vir poësie, vir verfyndheid en al die kwaliteite wat mense wesens makk wat ten opsigte van kompleksiteit ver bokant -114- 
ander wesens verhewe is. Om te glo dat die brein bloot uit 'n reeks chemiese reaksies bestaan is om wilsvryheid te negeer, om mense se verantwoordelikheid vir hulle dade te verwyder, om die relasie tussen sonde en skuld uit te skakel (Koshland, 1987).

Resente bevindings dui al hoe meer op die ingewikkeldheid van gedragspatrone by die mens. Diegene wat wegskram van die idee van kompleksiteit sal probeer om hierdie getuienis te reduseer na die ou konfrontasie van uiterstes; chemiese reaksies versus viye wil, oorerwing versus verwerwing, noodlot versus verantwoordelikheid. Die neurobiologiese getuienis dui duidelik daarop dat die brein van die mens deels aangebore kennis en vermoëns het en deels die vermoë het om deur ondervinding te leer. Daar moet ook daarteen gewaak word dat wanneer kinders hulle nie gedra nie, slegs ouers of skole die skuld daarvoor moet kry. As gevangenes nie gerehabiliteer word nie, lè die fout nie noodwendig by gevangenisprogramme nie. As selfmoorde nie verhoed word nie, moet nie slegs stres geblameer word nie. Net so simplisties is die opvatting dat daar geen misdaad is nie, slegs siektetoestande; geen skuld nie, slegs 'n slegte geenkombinasie. Die waarheid is daarin geleë dat ons met ' $n$ komplekse probleem te make het wat baie fasette het en nie met een bepaalde voorskrif reggedokter kan word nie. Beter skole, 'n beter omgewing, beter raadgewing, en beter rehabilitasie sal sommige. maar nie alle individue help nie. Oorerwing en verwerwing is verskynsels wat albei ' $n$ rol speel, en dit is moeilik om altyd te kan bepaal watter een op die voorgrond is.

Die mens is maar een van die wisselwerkende faktore in die aarde se ekostelsels, maar hy is sekerlik die magtigste spesie ten opsigte van wysigings van heersende ekologiese prosesse. Daarom is sy verantwoordelikheid teenoor die omgewing ook ordes groter as die van ander spesies. Hierdie verantwoordelikheid wat uitgeoefen word as bestierder en bewaker is ' $n$ imperatief wat gebaseer is op die mens se unieke eienskappe wat hom in staat stel om - in teenstelling met ander spesies - willekeurige beheer uit te oefen oor sy omgewing, sy eie bevolking. sowel as sy gedrag en genetiese erfenis. Die mens kan en moet dus 'n ekologiese gewete ontwikkel, asook 'n begrip, liefde, respek en bewondering vir die hele ekostelsel waarin hy hom bevind (Ryke, 1987d).

$-115-$ 
Die belangrikste medebewoners in die ekostelsel is egter die mens se spesiegenote. Elke mens het vermoëns wat hom in staat stel om nie slegs homself te kan help nie, maar ook om ander mense by te staan. So 'n verantwoordelikheidsgevoel teenoor sy medemens is eintlik 'n noodsaaklike eienskap vir uiteindelike oorlewing van in gemeenskap. Dieselfde geld ook vir die gemeenskap as geheel. As een mensgemeenskap sy kultuur ten koste van 'n ander gemeenskap en sonder hulle samewerking ontwikkel, word die saad vir sy eie vernietiging gesaai, want alle mense is deel van die natuur. As sekere mensgroepe so teen hulle medenatuurgenote optree, wyk hulle af van sekere basiese beginsels van menswees en die uiteinde kan katastrofies wees. Die uniekheid van die mens bied aan hom egter al die biologiese kwaliteite wat nodig is om deur sy geestelike vermoëns 'n sukses van sy bestaan op aarde te maak.

BIBLIOGRAFIE

ALCOCK, J. 1984. Animal behavior. An evolutionary approach. Sunderland, Mass : Sinauer.

ANDREW, R.J. 1965. The origins of facial expressions. Scient. Amer., 213:88-94.

AYALA, F.J. \& VALENTINE, J.W. 1979. Evolving. The theory and processes of organic evolution. Menlo park, Calif. : Benjamin/Cummings Publ. Co.

BEALS, R.L., HOIJER, H. \& BEALS, A.R. 1977. An introduction to anthropology. London : Collier Macmillan.

BICKERTON, D. 1983. Creole languages. Scient. Amer., $249(1): 108-115$

BOLK, L. 1926. Das Problem der Menschwerdung. Jena : Gustav Fischer.

BOURGUIGNON, E. 1976. Psychological anthropology. An introduction to human nature and cultural differences. New York: Holt, Rinehart $\varepsilon$ Winston. 
BRONOWSKI, J. 1973. The ascent of man. London : BBC.

BRUCE, E.J. \& AYALA, F.J. 1979. Phylogenetic relationship between man and the apes : Electrophoretic evidence. Evolution, 33.

CAMPBELL, B.G. 1976. The evolutionary emergence of language. (In Hammond, P.B., red. Physical anthropology and archaelogy. London : Macmillan. P. 33-42.)

CHOMSKY, N. 1972. Language and mind. New York: Harcourt Brace, Jovanavich.

DICKERSON, R.E. 1980 (March). Cytochrome $C$ and the evolution of energy metabolism. Scient. Amer. Reprint 1464.

EIMAS, P.D. 1975. Speech perception in early infancy. (In Cohen, L.B. $\varepsilon$ Salapatek, $P$. red. Infant perceptions from sensation to cognition. New York : Academic Press. p.193-231.)

EIMAS, P.D. 1985. The perception of speech in early infancy. Scient. Amer., 252(1):34-40.

FALK, D. 1987. Brain lateralization in primates and its evolution in hominids. Yearbook Phys. Anthrop., 30:107-125.

PERRY, J., red. 1984. The understanding of animals. Oxford : Blackwell and New Scientist.

GALABURDA, A.M., LEMAY, M., KEMPER, T.L. \& GESCHWIND, N. 1978. Right-left asymmetries in the brain. Science, 199:852-856.

GARDNER, R.A. E B.T. 1969. Teaching sign language to a chimpanzee. Science, 165:664-672.

GARDNER, R.A. E B.T. Early signs of language in child and chimpanzee. Science, 187:752-753. 
GARDNER, R.A. \& B.T. 1978. Comparative psychology and language acquisition. Ann. N.Y. Acad. Sci., 309:37-76.

GESCHWIND, N. 1970. The organization of language and the brain. Science, $170: 940-944$.

GOLDIN-MEADOW, S. \& FELDMAN, H. 1977. The development of language-like communication without a language model. Science, $197: 401-403$

HALLOWELL, A.1. 1960. Self, society and culture in phylogenetic perspective. (In Tax. S., red. Evolution after Darwin. Vol. 2. The evolution of man: Mind, culture and society. Chicago : Univ. Chicago Press.)

HASEGAWA, M., KISHINO, H. $\varepsilon$ YANO, T. 1985. Dating of the human-ape splittıng by a molecular clock of mitochondrial DNA. J. Mol. Evol., 22:160-174.

HAYES, C. 1951. The ape in our house. New York: Harper \& Row.

HOCKETT, C.P. \& ASCHER, R. 1964. The human revolution. Curr. Anthrop., 5:135-168.

ISAAC, G. 1983. Aspects of human evolution. (In Bendall, D.S., red. Evolution from molecules to men. Cambridge : Cambridge Univ. Press. p.509-543.)

JERISON, H.J. 1975. Author's precis and reply, C.A. Book review of Evolution of the brain and intelligence. Current Anthrop., 18:415-426.

KIMURA, D. 1973. The asymmetry of the human brain. Scient. Amer., 228(3):70-78.

KING, M.C. $\varepsilon$ WILSON, A.C. 1975. Evolution at two levels in humans and chimpanzees. Science, 188:107-116. 
KORTLANDI, A. 1973. Comment on primate communication and gestural origin of language, by C.W. Hewes. Current Anthrop., 14:13-14.

KOSHLAND, D.E. 1987. Nature, nurture and behavior. Science, 235: 1445 .

KREBS, J.R. \& DAWKINS, R. 1984. Animal signals: Mind reading and manipulation. (In Krebs, J.R. E Davies, N.B., red. Behavioral ecology: An evolutionary approach. Sunderland, Mass. : Sinauer. p.385-402.)

LENNEBERG, E.H. 1968. The biological foundations of language. New York : Wiley

LEWIN, R. 1982. How did humans evolve big brains? Science, $216: 840-841$.

LEWIN, R. 1987. The origin of the modern human mind. Science, 236: 668-670.

LEWONTIN, R.C. 1978. Adaptation. (In Evolution. Scientific American, Sept. 1978:114-130.)

LIEBERMAN, P., CRELIN, E.S. \& KLATT, D.H. 1972. Phonetic ability and related anatomy of the new-born and adult human, Neanderthal man and the chimpanzee. Amer. Anthrop., 74:287-307.

LORENZ, K.Z. 1935. Der Kumpan in der Umweld des Vogels. J. Ornithol., 83:137-213; 289-413.

MARX, J.L. 1980. Ape-language controversy flares up. Science, $207: 1330-1333$.

NAPIER, J. 1967. The antiquity of human walking. Scient. Amer., 216(4) : 56-66.

PENFIELD, $W$. \& ROBERTS, L. 1959. Speech and brain mechanisms. New Jersey : Princeton Univ. Press.

-119 - 
PILBEAM, D. 1984. The descent of hominoids and hominids. Scient. Amer., 250(3):60-69.

POIZNER, H., KLIMA, E.S. \& BELLUGI, U. 1987. What the hands reveal about the brain. Cambridge, Mas. : MIS Press.

PREMACK, A.J. \& D. 1972. Teaching language to an ape. Scient. Amer., 227(4):92-99.

PREMACK, D. 1971. Language in the chimpanzee? Science, 172:808-822.

PREMACK, D. 1976a. Intelligence in ape and man. Hillsdale, N.J. Halsted press.

PREMACK, D. 1976b. Mechanisms of intelligence: Preconditions for language. Ann. N.Y. Acad. Sci., 280:544-561.

PRIBRAM, K.H. 1977. Hemispheric specialization: evolution or revolution. Ann. N.Y. Acad. Sci., 299:18-22.

RUMBACH, D., red. 1977. Language learning by a chimpanzee: The Lana project. new York: Academic Press.

RUMBACH, D. \& GILL, J.V. 1976. Language and the acquisition of language-type skills by a chimpanzee (Pan). Ann. N.Y. Acad. Sci., 270:90-123.

RYKE, P.A.J. 1986. Neotenie en evolusie. S. Afr. J. Sci., 82:426-431.

RYKE, P.A.J. 1987a. Aard en oorsprong van bipedalisme by primate. S. Afr. Tydskrif vir Natuurwetenskap en Tegnologie, 6(2):72-81.

RYKE, P.A.J. 1987b. Evolusie. Potchefstroom : DSP, PU vir CHO.

RYKE, P.A.J. 1987c. Die sosiobiologiepolemiek. Koers, 52(2):88-114. 
RYKE, P.A.J. 1987d. Man's impact on the environment. Koers, $52(4): 440-480$.

SAVAGE-RUMBAUGH, E.S., RUMBAUGH, D.M. \& BOYSEN, S. 1980. Do apes use language? Amer. Scientist, 68:49-61.

SPKIINER, B.F. 1938. The behavior of organisms. New York : Appleton-Century-Croft.

STRINGER, C. 1982. The evolution of man. New Scientist, 94:152-155.

TERRACE, H.S., PETITTO, L.A., SANDERS, R.J. \& BEVER, T.G. 1979. Can an ape create a sentence? Science, 206:891-206.

TUTTLE, R.H. 1969. Knuckle-walking and the problem of human origins. Science, 166:953-961.

VAN LAWICK-GOODALL, J. 1968. The behavior of free-living chimpanzees in the Combe Stream Reserves. Animal Behavior Monographs, 1:165-311.

VAN LAWICK-GOODALL, J. 1971. In the shadow of man. Boston Houghton Mifflin.

WADE, N. 1980. Does man alone have language? Apes reply in riddles, and a horse says neigh. Science, 208:1349-1351.

WASHBURN, S.L. 1978. The evolution of man. (In Evolution. Scientific American Book.)

WEISS, M.L. 1987. Nucleic acid evidence bearing on hominoid relationships. Yearbook Physical Anthrop., 30:41-73.

WHEELER, P. 1988. Stand tall and stay cool. New Scientist, 12:62-65, May. 